Utah State University

DigitalCommons@USU

All PIRU Publications

Pollinating Insects Research Unit

11-14-1946

\title{
Lizards Feeding on Ants in Utah
}

George F. Knowlton

William P. Nye

Utah State University

Follow this and additional works at: https://digitalcommons.usu.edu/piru_pubs

Part of the Entomology Commons

\section{Recommended Citation}

Knowlton, G. F., and W. P. Nye. 1946. Lizards Feeding on Ants in Utah. J. Econ. Entomol. 39(4): 546, table.

This Article is brought to you for free and open access by the Pollinating Insects Research Unit at DigitalCommons@USU. It has been accepted for inclusion in All PIRU Publications by an authorized administrator of DigitalCommons@USU. For more information, please contact digitalcommons@usu.edu.

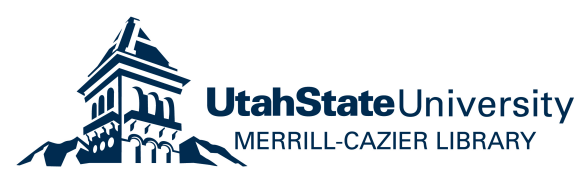




\section{Lizards Feeding on Ants in Utah}

George F. Knowlton and William P. Nye, Utah Agricultural Experiment Station, Logan

Ants are directly responsible for a reduction in the livestock carrying capacity of Utah range lands. Harvester ants, and in particular Pogonomyrmex occidentalis (Cresson), clear all vegetation from large spots surrounding each of their nests. Thousands such large bare spots are cleared off by ant colonies on range land and in alfalfa fields in Utah. Harvester ants also reduce range forage by bringing to their nests large numbers of seeds and plant stems. The bare spots around $P$. occidentalis mounds range in
Desert scaly lizards had fed on ants to the extent that 755 were counted in 29 of the 49 stomachs examined.

The sagebrush swift is so common as to be important in control of range insects in many brushy areas. At Blanding, 1662 ants were contained in 107 of the 185 stomachs taken, At Cedar, in Emery County, 850 ants were recognized in 121 of the 196 stomachs collected, while at Kanab, 909 ants were present in 70 of the 123 stomachs. Collections at $\mathrm{Mt}$. Carmel revealed 552 ants in 43 stomachs of the 80 sagebrush swifts collected.

In a rabbitbrush-sagebrush pasture west of Orem, in Utah County, in which the sagebrush swift was

Table 1.-Number of ants found in stomachs of 12 lizard species.

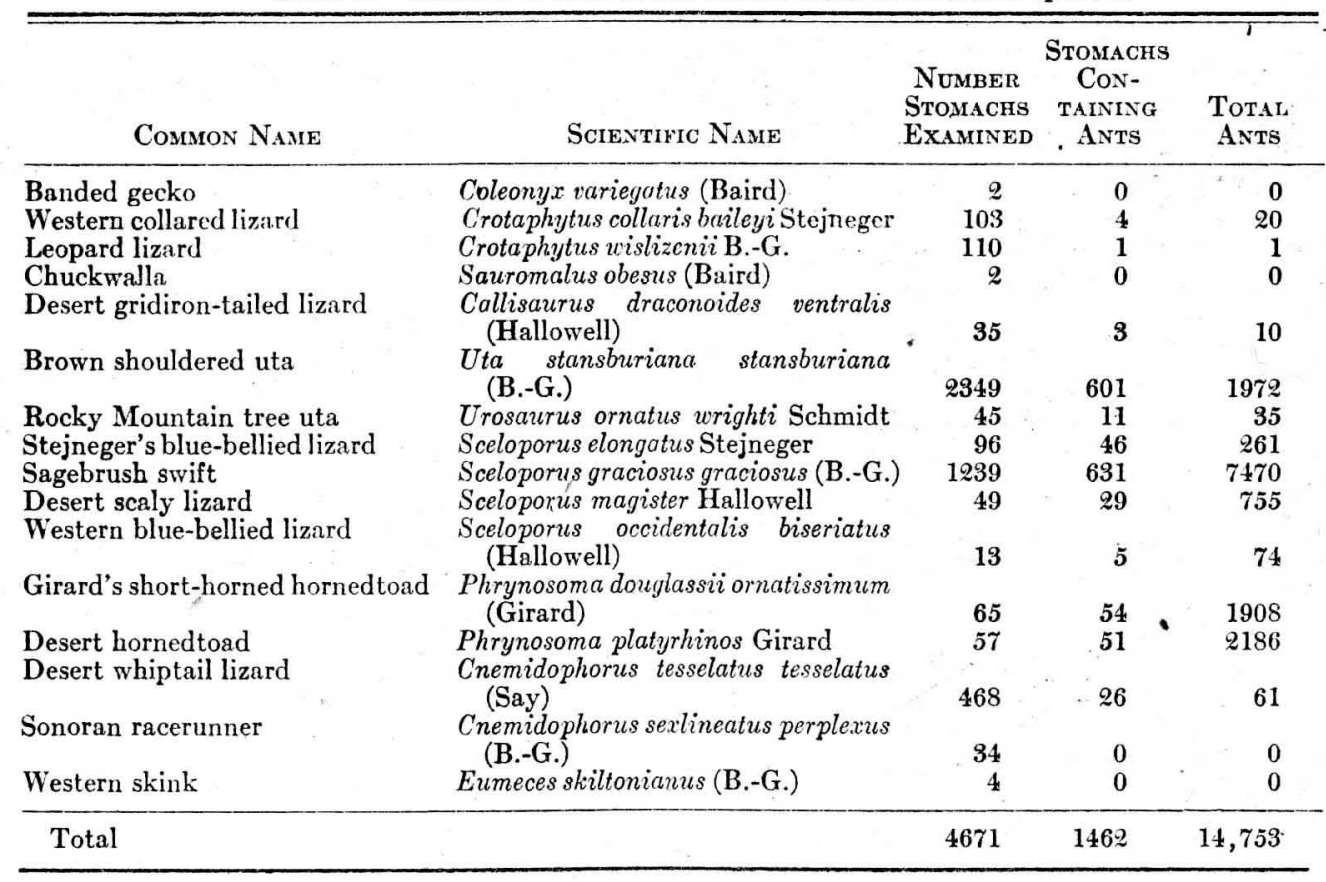

diameter from 10 to 43 feet. Other injurious ants make nests in lawns, gardens, build mounds which damage mowing equipment in fields, attack wood, attend injurious species of aphids and related honeydew producing insects. Although ants confer some benefits by consuming dead and decomposing insects and other small organisms, they are economically undesirable from the stand point of crop and livestock production in Utah. Cole ${ }^{2}$ in 1942 recorded 104 species, subspecies, and varieties of ants as occurring in Utah.

An examination of 1462 stomachs of 16 species and subspecies of lizards, collected in Utah since June, 1930 , showed they contained a total of 14,753 ants. Many other injurious and undesirable insects also were present.

Stomachs of only four of the lizard species contained no ants. The chuckwalla fceds chiefly on flowers, buds, and leaves of plants. Two stomachs of the banded gecko, four of the western skink and 34 stomachs of the sonoran race runner held no ants in recognizable condition. The latter species and the desert whiptail lizard feed more commonly on caterpillers, beetles, grasshoppers, and other insects of larger size than most of the common ants.

The horned toads feed extensively on ants. Of 65 stomachs of Girard's horned toad examined, 54 contained a total of 1908 ants. Examination of 57 stomachs of the desert horned toad rsvealed 2186 ants in $\tilde{51}$ of the stomachs.

1 Research professor and graduate assistant, respectively

2 Cole, A. C., Jr., Ants of Utah, Amer. Midland Nat., 28: $358-388,1942$ extremely abundant, 3497 ants were recognized in 290 of the $655 \mathrm{~S}$. g. graciosus stomachs examined. It was estimated that more than 1000 swifts per acre were present in brushy margins of this pasture. A total of 7470 ants were found in the stomachs of 631 Sceloporus g. graciosus, out of a total of 1239 stomachs examined from the above named localities. From a study of 2191 sagebrush swift stomachs taken in Utah, Knowlton, et al. recorded a total of $11,47 \mathcal{2}$ ants out of a total of 12,267 Hymenoptera recognized.

The brown-shouldered uta is probably the most abundant lizard over much of the arid semidesert area in Utah. The senior writer has estimated that from 100 to more than 300 specimens of this lizard often occur per acre on favorable range feeding areas of Tooele and Box Elder Counties. Of specimens collected west of Skull Valley, in the general vicinity of Delle, 541 ants were found in 147 of the 464 stomachs examined. In the Dolomite area 514 ants occurred in 183 of the 643 stomachs. At Iosepa in Skull Valley, Tooele County, 171 ants were recorded from 75 stomachs out of 653 examined. At Timpie, 646 ants were present in 196 of the 589 uta stomachs. The total of the above shows 1972 ants still in recognizable condition in 601 of the 2349 stomachs. This common uta evidently feeds less generally on ants than horned toads and sagebrush swifts.

As shown in table 1, this study revealed the occurrence of 14,753 ants in recognizable condition in 1462 of the 4671 lizard stomachs examined. From this the writers would conclude that insectivorous lizards are of importance in the biological control of ants in many range areas of Utah.-4-1-46. 